\title{
Freedom of Association in Vietnam: A Heretical View
}

\author{
Joe Buckley, Independent Researcher, United Kingdom
}

\begin{abstract}
Vietnam is a one-party state with a single state-led union federation and significant numbers of wildcat strikes. In January 2021, independent worker representative organisations became legal. The reforms are creating significant excitement among labour watchers and practitioners. This article, however, provides a more sceptical tone. Drawing on Atzeni's critique of trade union fetishism, I argue that, rather than being a progressive step forward, freedom of association reforms are an attempt to reduce labour militancy. First, Vietnam is implementing reforms while further embedding itself into neo-liberal capital flows and global production networks - the very form of capitalism that undermined trade unionism elsewhere. Second, workers have been using effective forms of self-organised, wildcat militancy for two decades, which has led to significant improvements in terms of wages, conditions and national policy. The current organisational form of wildcat strikes does not easily fit into a worker representative organisation (WRO) structure. Third, because existing forms of resistance have worked, workers have not been demanding independent organisations. Rather, such demands have come from capital. Previous attempts to build harmonious labour relations by reducing militancy through incorporating class antagonisms into non-threatening forms have failed. Consequently, capital has now embraced ideas around freedom of association as an attempt to tame worker resistance.
\end{abstract}

\section{KEYWORDS}

Strikes; unions; freedom of association; Vietnam; WROs

\section{Introduction}

Vietnam is a one-party state which does not currently allow freedom of association; there is a single, state-led union federation, the Vietnam General Confederation of Labour (VGCL). There are also significant numbers of wildcat strikes in the country - the VGCL has never led a strike - which have led to various attempts by the state to reduce strikes through building "harmonious labour relations" (quan hệ lao động hài hoä). These attempts have largely failed to stem strike numbers. There were big changes, however, on 1 January 2021. From that date, Vietnam, for the first time, allowed worker representative organisations (WROs) not attached to the VGCL. WROs are not unions, but are allowed to engage in collective bargaining and strike organisation at the enterprise level.

The reforms are creating significant excitement among labour watchers and practitioners. In this article, however, I strike a more sceptical note. I draw on Atzeni's $(2020,2021)$ critique of "trade union fetishism", which criticises labour studies research for often focusing on the trade union form and hiding from view actual processes of class struggle, separate from unions. I argue that we should dispense with trade union fetishism and, rather than considering Vietnam's reforms in comparison to an imagined ideal of free trade unionism and tripartism, assess them in 
comparison to actually existing class composition and struggle. From this perspective, I contend that, rather than being a progressive step forward, freedom of association reforms are an attempt by capital to reduce labour militancy. Workers have been using effective forms of self-organised, wildcat militancy for two decades, which have led to significant improvements in terms of wages, conditions and national policy. Concurrently, Vietnam's "hyper-liberal" (Masina and Cerimele, 2018: 298) capitalism is the same neo-liberalism which has served to totally undermine independent trade unions in places where they were once effective. Because existing forms of resistance have worked in Vietnam, workers have not been demanding independent organisations. Rather, such demands have come from capital. Previous attempts to build harmonious labour relations by reducing militancy through incorporating class antagonisms into non-threatening forms have failed. Consequently, capital has now embraced ideas around freedom of association as an attempt to tame worker resistance. This article therefore contributes to knowledge both empirically and theoretically, showing how an analytical shift away from trade union fetishism and towards a class analysis can make visible problems which are hidden by the fetishism of trade unions.

I first outline the current situation of labour politics in Vietnam, before explaining what the reforms are, and where they have come from. I then explain some of the existing critiques of WROs; they are not unions and are limited in what they can do compared to unions, especially in an authoritarian context. I suggest, however, that once we reject trade union fetishism, there are more fundamental critiques to be made. First, Vietnam is implementing freedom of association reforms while further embedding itself into neo-liberal capital flows and global production networks - the very form of capitalism that has undermined trade unionism in other parts of the world. In this epoch, wildcat strikes have been effective. In contrast, it is difficult to see how a WRO-led strike, requiring a complex bureaucratic procedure, would work; it could give employers adequate time to neutralise the strike's impact, hire scab labour, fire strike leaders and employ other WRO-busting strategies. Second, the current organisational form of wildcat strikes does not easily fit into a WRO structure. Third, workers are not demanding WROs; capital is.

The argument is developed as the result of extensive fieldwork in Vietnam, from July 2017 to June 2018. Research focused on the garment and textile industry in southern Vietnam. This is the sector and region in which most strikes occur. Fieldwork involved semi-structured interviews with ninety participants, comprising fifty-three workers, twenty managers and owners, and seventeen others, including government and union officials, independent labour activists, CSR officers, journalists and labour lawyers. Worker participants were found through opportunity and snowball sampling. I also employed the factory gate technique, waiting in coffee shops near factories in order to speak to workers. Employer and other participants were chiefly found through mutual acquaintances and contacts. Such a research approach provided insight into how worker resistance is organised on the ground, and how detached this is from national-level policy discussions.

\section{Vietnamese Labour Politics and Freedom of Association Reforms}

Two observations are most important for understanding contemporary labour politics in Vietnam. First, there is a single, state-led union federation, the VGCL. The VGCL is part of the Vietnam Fatherland Front, the group of mass organisations led by the Communist Party of Vietnam (CPV). In the mode of Leninist dual-functioning unions, ${ }^{1}$ the VGCL sees its functions as, simultaneously,

\footnotetext{
${ }^{1}$ The notion of dual-functioning unions is a doctrine which emerged from the tenth Congress of the Russian Communist Party in 1921, in which the role of unions in socialist societies is to encourage productivity while also protecting workers from harsh treatment (Pravda and Ruble, 1986: 2).
} 
to help increase productivity, to protect workers' rights and interests, and to propagate party directions and mobilise workers (VGCL, 2014: 269). The VGCL has both sectoral unions and regional federations. In addition to being dominated by the party at the national level, the VGCL is dominated by employers at the enterprise level. Trade union representatives are often members of management, such as human resource managers or similar (Do and Broek, 2013).

Second, there are hundreds of wildcat strikes each year, and have been since the first decade of the twenty-first century. Siu and Chan (2015: 71) claim, "In no other Asian country, not even in neighbouring China where strikes have become a grave concern for the Chinese state and capital alike, has there been such a high number of reported strikes". While strikes were legalised in 1994, organising a legal strike requires workers to pass through a number of lengthy bureaucratic procedures, including the condition that strikes are led by the VGCL, which that organisation has never done. Every strike is, therefore, technically unlawful and wildcat. Strikes are overwhelmingly, but not exclusively, in industrial sectors. ${ }^{2}$

The vast majority of strikes are over wages or working conditions. Demands are frequently met, and often with remarkable success. Clarke (2006: 349) analyses the outcomes of seventy-one strikes, finding that "workers' key demands were met in 68 cases". In 95 per cent of the strikes Anner (2015: 26) studied, at least one of the workers' demands were met. According to a 2011 survey commissioned by the International Labour Organization (ILO), employers accepted all the workers' demands in 90 per cent of strikes (Do, 2017: 1058). Another report says 80 per cent (Daubler, 2018: 153). It would be a mistake, though, to think that the impacts of strikes are limited to these immediate demands, that employers simply placate striking workers by throwing them a few dollars before resuming production and exploitation as before. Strikes have also forced significant broader changes, such as wage rises keeping pace with productivity rises (Gray, 2018), the development of a system for annual minimum wage fixing (Tran, 2007) and legal reform (Do, 2016). They have also forced changes to national-level policy, such as twice reversing proposed revisions to the social insurance law (Clarke, 2006; Tran, 2015), and playing a part in compelling the government to shelve a proposed law on special economic zones (Tran, 2018). Strikes also played a role in Vietnam's successful containment of the COVID-19 pandemic (Buckley, 2020b).

There have been a number of different attempts by sections of the state, capital and the union to reduce the number of strikes through building harmonious labour relations, including several prominent industrial relations reforms. These have included the creation of a National Wage Council (Hội đồng tiền lương quốc gia) (ILO, 2013), collective bargaining experiments (Quan, 2015; Pham, 2019), and the development of dispute resolution mechanisms (Cooney and Tran, 2019). While such attempts have led to significant changes, they have largely failed in their overall aim to stem strike numbers.

But changes are afoot. On 14 June 2019, the National Assembly voted to ratify the ILO's Convention 98 on the Right to Organise and Collective Bargaining (ILO, 2019a), and formally deposited the instrument of ratification of the convention with the ILO on 5 July 2019; it came into force on 5 July 2020 (ILO, 2019b). The convention prevents workers' and employers' organisations from interfering with each other's activities. On 20 November 2019 a new Labour Code was passed, which became law on 1 January 2021; among other things, it allows workers to join "worker representative organisations" (tổ chức đại diện người lao dộng) which are not subordinate to the VGCL or the CPV (Bộ luật Lao dộng 2019, chương XIII). The country plans to ratify ILO Convention 87 on Freedom of Association and Protection of the Right to Organise by

\footnotetext{
${ }^{2}$ In recent years, for example, the gig economy - especially ride-hailing and delivery apps - has become an emerging site of class struggle (Buckley, 2020a).
} 
2023 (ILO, 2019a).

The reforms are creating significant attention and excitement among labour scholars and practitioners. The ILO says that Vietnam's ratification of Convention 98...

...highlights the endeavour of the Government to achieve, jointly with the social partners, the labour and economic conditions that lay the foundations for the sustainable development of the country. It is expected that ratification of Convention No. 98 will contribute to further accelerate the spread of genuine collective bargaining across Vietnam, which is likely to result in better working conditions, higher productivity and shared prosperity (ILO, 2019b).

Tran and Bales (2017: 72, 93), writing when freedom of association was being considered, said there were "positive signs for rapid labor reform" and that allowing worker organisations not subordinate to the VGCL would be "a significant step forward". During debates over the new Labour Code, the Friedrich Ebert Stiftung called the reforms "an important opportunity to ensure sustainable development by protecting workers' rights" (FES, 2018). Lee, the director of ILO Vietnam, says that the new Labour Code “will substantially improve Viet Nam's employment and industrial relations" (in ILO, 2019c).

\section{Where Have Reforms Come From?}

A number of trade deals in which Vietnam has been involved have included labour rights provisions: the Trans-Pacific Partnership (TPP), the Comprehensive and Progressive Agreement for Trans-Pacific Partnership (CPTPP), and the European Union-Vietnam Free Trade Agreement (EVFTA). During negotiations over the original TPP, the United States and Vietnam signed a bilateral side agreement which outlined the freedom of association reforms which Vietnam would have to implement (United States-Viet Nam Plan for the Enhancement of Trade and Labour Relations, 2016). According to this agreement, the country had to agree to permit workers to form a grassroots labour union without prior authorisation, which would then register with either the VGCL or a competent government body. Such labour unions could form or join organisations of workers across enterprises and at higher levels, including the sectoral and regional levels. The agreement also included a proviso that the United States could withhold or suspend tariff reductions if Vietnam failed to implement the required reforms. After the United States withdrew from the TPP in 2017, the agreement was de facto abandoned. The CPTPP - which was the reformed TPP without the participation of the United States - and the EVFTA had much vaguer labour provisions and enforcement mechanisms. Both agreements said only that signatories must ratify all eight of the ILO fundamental conventions, which include Convention 87 on the Right to Organise and Collective Bargaining and Convention 98 on Freedom of Association and Protection of the Right to Organise (Comprehensive and Progressive Agreement for Trans-Pacific Partnership 2018; EUVietnam Free Trade Agreement 2018, chapter 13; see also Tran, Bair and Werner, 2017).

Researchers generally see Vietnam's labour reforms as a result of the requirements of these trade deals. Pham $(2016,2017)$, for example, who has worked in both academia and government, having held positions in the Ministry of Labour, Invalids and Social Affairs (MOLISA) and at the National Assembly, argues that Vietnam's labour law reforms are entirely due to the requirements of the TPP, and that although the United States withdrew from the agreement, the negotiations provided the momentum for reform. Tran et al. (2017: 410) argue that it was the TPP which led to significant reforms regarding freedom of association being proposed, and that the US withdrawal and subsequent annulment of the labour side agreement "had a clear and immediate effect on the 
strength of freedom of association articles in the labour code reform process"; that is, they were significantly weakened. In contrast, they argue that Vietnam's proposal of much weaker freedom of association reforms post-TPP, while EVFTA negotiations were still ongoing, suggest that the "Vietnamese government is not particularly concerned about [freedom of association] obligations" in the EVFTA, "or at a minimum, that the government does not believe it needs to implement, for the Europeans, the kind of domestic reforms spelled out in the TPP side agreement" (Tran et al., 2017: 412). They argue that this is because of "relatively weak post-facto enforcement provisions in the EVFTA" (Tran et al., 2017: 413). Tran and Bales (2017) outline the development of debates and discussions on freedom of association within Vietnam, noting that they began in 2014, when Vietnam started negotiating to join the TPP. They also note that "everything came to a screeching halt in late 2016 when it became clear that the United States planned to withdraw from the TPP negotiations", although in 2017 the draft Labour Code did contain some measures for limited freedom of association (Tran and Bales, 2017: 89). The fact that discussions on freedom of association continued after the TPP collapsed, albeit in more limited form, is, according to Tran and Bales (2017: 74), "perhaps a happy by-product of the TPP negotiations, or perhaps it stems in part from concerns of international investors or the internalization (to some degree) in Vietnam of the ILO labor norms". Do (2017: 1066, emphasis added), however, argues that the fact that freedom of association discussions continued post-TPP suggests that "the decision to recognize independent unions is not due to external pressure (from TPP and the USA) but rather the result of internal demand for reforms to the union system".

It is unfortunate that Do does not extend her analysis very far, as she makes an important point; other scholars tend to ignore the pressure from below - worker militancy - which has contributed to freedom of association reforms. We can bring these two perspectives together; freedom of association reforms in Vietnam are a result of pressure from both above and below. The pressure from below is wildcat worker militancy. Such militancy created pressure on the state to build harmonious labour relations so as not to repel capital investment. A number of initiatives have been tried, some of which are summarised above, but these have largely failed to stem militancy. Consequently, once freedom of association reforms became an important part of trade negotiations - pressure from above - elements of the state and capital became receptive to the idea, seeing it as an opportunity to build harmonious labour relations and stop strikes. This explains why freedom of association discussions continued even after the United States withdrew from the TPP.

\section{WROs and Liberal Critiques}

The WROs in the new Labour Code, referred to as "grassroots worker representative organisations" (tổ chức đại diện người lao động tại cơ sở) or "enterprise-level worker representative organisations" (tổ chức đại diện người lao động tại doanh nghiệp) (Bộ luật Lao động 2019, chương XIII), are not the same as trade unions (công doàn). Trade unions remain part of the VGCL and are legislated differently. There is a separate trade union law (Luật Công doàn 2012). WROs are legislated in Chapter XIII of the new Labour Code. WROs at the enterprise level are allowed to establish themselves and begin activities once a competent state agency has registered them. The registration will be withdrawn if the organisation is judged to have broken the law (including failing to be democratic or transparent) or if the enterprise at which they are formed ceases to exist through merger, acquisition, separation or closure. There is no clear legislation allowing WROs to grow beyond the enterprise level, linking with other WROs across sector or region. Article 174 makes a 
single, somewhat unclear reference to members of WROs being able to decide about mergers (sáp nhập) or linkages (liên kết ) of the organisation (Bộ luật Lao dộng 2019, chương XIII). Trade unions are allowed to partake in political and policy debates and discussions at all levels, from the national level down. WROs, in contrast, cannot take part in any such debates and discussions beyond the individual enterprise. Trade unions receive state support; independent WROs do not (Luật Công doàn 2012; Bộ luật Lao dộng 2019, chương XIII).

From a liberal perspective, there are some clear and serious critiques to be made of these reforms. A number of these are outlined by $\mathrm{Ca} \mathrm{DaO}$, the pen name of an independent labour activist based overseas, in a Vietnamese-language opinion piece. ${ }^{3}$ Ca Dao (2019) notes that the law states that WROs will only be legal after registering with the government, that registration procedures and numbers of members will be determined by the government, and that the government has the authority to provide operating licences to these organisations. She argues that this is contrary to the operations of free trade unions around the world, where unions themselves have the right to establish and operate without needing prior permission, and registration is simply an administrative procedure. Ca Dao likens this to a newborn baby, where registering the birth is an administrative procedure and the state does not have the right to say no to the baby's existence.

Ca Dao (2019) argues that the Vietnamese government is haunted by the Polish Solidarity movement, so is trying to greatly limit the ability of WROs to organise strikes and other actions. She notes that there is no law outlining in detail what worker representative organisations will be able to do, as the Trade Union Law only refers to the VGCL. She also argues that WROs will be kept weak because, while they are allowed to be formed within companies, they are not allowed to link across enterprises and so will be unable to develop. She predicts that the VGCL will also begin to call their enterprise-level unions "worker representative organisations" or that the VGCL will work with employers to form "worker organisations" which in practice will just be yellow unions; the word "independent" (dộc lập) is not found anywhere in the Labour Code (Ca Dao, 2019).

We could add two more general observations to Ca Dao's critiques. First, while discussions over the new Labour Code and of ILO Conventions 87 and 98 have been in progress, Vietnam has simultaneously been increasingly arresting and harassing activists and civil society organisations, including labour activists (Amnesty International, 2019). Even researchers investigating topics not normally considered especially controversial, such as workers' health, have been subjected to harassment from the authorities (United Nations, 2018). The free operation of WROs without employer or state interference is almost impossible in this situation, since that would be antithetical to an authoritarian state. This is exacerbated by the fact that leaders of WROs cannot have a criminal record, automatically excluding anyone whom the state arrests and charges (Bộ luật Lao động 2019, chương XIII). Second, the VGCL is well-funded and well-established at every level of society, from the national level down. This, combined with the fact that the VGCL will still receive support and backing from the state and be able to continue as a national-level organisation while WROs will not receive such support and there is no legislation allowing them to build or organise beyond individual enterprises, means that it will be very hard for such organisations to compete with (VGCL-affiliated) trade unions. As a result, we may see WROs choosing to affiliate to the VGCL and becoming trade unions; the Labour Code allows for this (Bộ luật Lao dộng 2019, chương XIII).

${ }_{3}^{3}$ The three main dissident labour rights organisations in Vietnam are the Vietnamese Independent Union, Viet Labour and Viet Labour Movement. 
These are legitimate critiques which should be taken seriously. In my view, however, there are other, more fundamental critiques to be made. To see these, we need to break out of "trade union fetishism" (Atzeni, 2020, 2021).

\section{Fundamental Critiques: Ditching Trade Union Fetishism}

Atzeni $(2020$, 2021) critiques what he calls "trade union fetishism" - the tendency for labour studies researchers to reify trade unions as the ultimate expression of workers' organisation. Where trade unions were once the expression of a social relation - the labour-capital antagonism - and effective at a certain historical juncture, they have now become fetishised as the ultimate workers' organisational form. This, argues Atzeni, hides from view actual processes of class formation and struggle:

The dependency of research on the trade union as the par excellence form of organisation is creating a fetish of the union form, an interest in the form itself that hides from view broader processes of struggle and collective formation and of working-class mobilisations outside/in parallel/alternative to the union form (Atzeni, 2020: 311, emphasis in original).

He suggests that trade union fetishism needs to be abandoned in order to rediscover contemporary class composition (Atzeni, 2020, 2021).

This is what we see in the Vietnamese case. Rather than looking at what is present in existing labour activism, such as a specific class composition or certain forms of solidarity, researchers often fetishise the trade union form; they note the absence of genuine tripartite labour relations structures, and assume that such structures should be present. That is, studies of Vietnamese labour relations approach the topic with a pre-existing bias, assuming that the task for labour studies researchers and practitioners is to work out how genuine trade unions and tripartite mechanisms can be built, and to compare the existing situation to that ideal. Everything we have seen so far falls into this framing. Those who are positive about the WRO reforms, noted above, see them as a step towards genuine trade unionism, notwithstanding the limitations, and therefore as a positive. Those who critique the reforms, however, do so on the basis that they are still not full, genuine and independent trade unions.

The result of this is exactly what Atzeni warns about; it hides from view actual processes of class struggle. Let us, instead, change the frame of reference. Rather than comparing WROs to a reified ideal of the trade union form, we should compare them to actually existing social relations, class antagonisms and struggles. From this perspective, the extent to which WROs do or do not resemble "real" unions is not particularly important; what is important is where the reforms came from and how they relate to contemporary political economy and labour struggles.

Once we make this analytical shift, Vietnam's freedom of association reforms become even more problematic than already outlined. First, the country is implementing the reforms while further embedding itself into neo-liberal capital flows and global production networks - the very form of capitalism that undermined trade unionism in other parts of the world. Second, the current organisational form of wildcat strikes does not easily fit into a WRO structure. Third, workers are not demanding freedom of association; such demands have come from capital.

\section{WROs and neo-liberalism}

Vietnam's capitalism has taken a "hyper-liberal turn" since the mid-2000s (Masina and Cerimele, 
2018: 298), as the country has embedded itself into global, neo-liberal flows of capital. Masina and Cerimele (2018) argue that, consequently, low wages and poor working conditions have become a structural rather than a transitory factor for Vietnam's participation in global production networks. Employers in Vietnam use a number of tactics to keep workers fragmented and to undermine their power. These include manipulating labour contracts, paying piece-rate wages (Cerimele, 2018), and even fleeing the country - often with impunity - leaving behind weeks of unpaid wages and social insurance contributions (Tran, 2013: 216).

Vietnam is implementing freedom of association reforms while further rooting itself into neoliberal capital flows and global production networks through the CPTPP and EVFTA trade deals. ${ }^{4}$ These have "constrained the scope" of the government's available policy options (Fujita, 2020: 324). For example, in order to comply with trade deals' national treatment rules, the country has "retreated from targeted industrial policies" (Fujita, 2020: 324). This is the form of capitalism which contributed to the destruction of trade union power in the places where unions were once powerful, the Global North (Breman and Van der Linden, 2014; Van der Linden, 2016). It does not bode particularly well for WROs.

In contrast, wildcat strikes are effective. Alquati, writing about the FIAT factory in Turin in 1963, explains why workers like the wildcat strike strategy:

a) it demands an 'invisible organization' that does not institutionalize itself as an autonomous organization within the capitalist production process; b) it actualizes itself through a continuous and unpredictable rotation of the tactics, methods, times, and places of the strike; c) it demands nothing (Alquati, 2013, emphasis in original).

Wildcat strikes in Vietnam have very concrete demands. The first two points, however, are true in Vietnam. Regarding b), especially, we can see how this is an appropriate form of struggle for workers at the sharp end of neo-liberal production networks. Employers are forced to respond immediately, especially if workers strike "precisely when a supplier needs to ship a product to a buyer" (Anner, 2018: 77).

Strikers' demands for higher wages or better working conditions are frequently met. As discussed above, though, achievements are not limited to these enterprise-level issues, but have also caused more broad-ranging changes in policy, law and industrial relations practices. Indeed, the reforms allowing WROs can be seen as a result of wildcat strike action. In contrast, a WROled strike will be legal but requires workers to pass through a number of bureaucratic procedures before launching it. It is difficult to see how this would work in the current epoch. It would give employers adequate time to neutralise the strike's impact, hire scab labour and fire strike leaders. They would also be able to employ other union-busting strategies found almost anywhere in the world.

\section{The wildcat strike form}

Van der Linden (2008), in his typology of unions, suggests that wildcat strikes often take the form of "mushroom unions". He defines these as trade unions which "are formed at the start of, or during a strike, and disband quickly afterwards (regardless of whether the strike ends in victory, defeat, or compromise)"; they therefore resemble mushroom clouds (Van der Linden, 2008: 226). These are not officially recognised worker organisations but do resemble a trade union in their

\footnotetext{
${ }^{4}$ And, more recently, the Regional Comprehensive Economic Partnership (RCEP) (Trade Justice Pilipinas, 2020).
} 
structure. Van der Linden draws on a number of historical examples, from Argentina, Britain, India, Nigeria and the United States. For more recent examples of a strike organisational form which could be defined as a mushroom union, we can look to the work of Campbell (2013) on Burmese migrant factory workers in Mae Sot, Thailand. He recounts an example where an initial factory walk-out became an extended and well-organised wildcat strike, with a strike negotiation committee, clear channels of communication and a communal space set up at a monastery. The striking workers won almost all of their demands. Campbell does not use the term mushroom union, but the wildcat strike clearly represented such an organisation - containing strike committees, channels of communication and decision-making, and pooled resources - which then disbanded at the end of the dispute.

Wildcat strikes in Vietnam, however, have a different "invisible organization" (Alquati, 2013). The strike form does not resemble or mirror the structure of a union-led strike, but is much more decentralised. There are no central organising committees or rotas to allocate specific tasks to strikers. Rather, workers discuss and debate whether to go on strike on social media, through signs stuck on toilet walls or graffiti written on the walls directly (see Tran, 2013: 209-210 for images of such graffiti). Sometimes, leaflets calling for strikes are distributed. Within the whole group, small groups of workers take additional, autonomous actions, such as throwing shrimp paste (mă $m$ tôm) and rotten eggs to stop strike-breakers, making banners or collecting money to provide strikers with food and drink (triangulated from eighteen interviews, comprising fourteen workers, three independent labour activists and a labour journalist, 22 July 2017 to 25 June 2018).

There is, of course, variation in the exact form that strikes take. One example concerns strike leaders. There is broad scholarly agreement that strikes ${ }^{5}$ are led by informal leaders (Clarke, 2006; Pringle and Clarke, 2011; Cox, 2015; Siu and Chan, 2015; Do, 2017; Daubler, 2018; Kerkvliet, 2019). The concept and role of informal leaders, however, needs rethinking. I have found that sometimes, strikes have no recognised leaders at all; nobody knows who begins the strike and the first person to call for a strike or walk off the job may not even have known themselves. Tran recounts interviewing a worker about a strike he had been involved in. The worker stressed that "we went on strike ourselves. No one led us" (Tran, 2013: 211, emphasis in original). Similarly, when a strike broke out at a large Taiwanese-owned shoe factory against a new salary policy at the beginning of 2018, workers from the section of the factory where the strike began were a little confused to be asked about who led the strike. One worker explained that there were no leaders. Rather, workers had been talking to each other about the issue, in person and on Facebook, and agreed they should strike. When it was put to him that, even without leaders, somebody would have to begin the strike, he concurred, but said nobody knew who that person was, and that nobody ever knows who begins a strike: "How can we possibly know that?" (interview, 14 April 2018). Other workers, from different sections of the factory, had similar responses; there were no leaders, only discussions between workers who decided to strike together (interviews with seven workers, 25 March to 14 April 2018). One worker, considered by management to be a troublemaker, was suspected of being a strike leader. As she explained, however, she was not on shift when the strike began, and did not know when it would occur (interview, 25 March 2018). Workers from other factories who had participated in other strikes also had similar experiences of leaderless strikes; there were discussions between workers, in person and on social media, through which a general consensus about whether or not to strike became clear (interviews with twelve workers, 4 March to 25 June 2018).

A number of interview participants who had been involved in multiple strikes talked of how

${ }^{5}$ As noted above, all strikes in Vietnam are wildcat strikes. 
some are leaderless, but others do have a form of leadership (four interviews with workers, 18 March to 5 May 2018). This is temporary and rotating. At certain times, individuals volunteer themselves for specific tasks, such as presenting demands to management or being part of strike negotiations. They are then replaced by others, who perform different tasks. Temporary, rotating leadership serves two purposes. First, it can act as a bulwark against employers singling out individual leaders who could then be sacked or victimised after the strike resolution. Two workers recalled strikes they were previously involved in - one was in 2003 or 2004 and the other was in 2014 or 2015 - which were unusual as they did have a person who identified themselves as a leader throughout the strike; these people were then fired (two interviews, 29 April and 10 June 2018). In contrast, temporary, rotating leadership makes it much more difficult to single out leaders. Second, temporary and rotating leadership avoids the issue of leaders being bought off by management, through being offered promotions or pay rises, and therefore losing the trust of workers. Do (2011: 165) finds that this happened after a 2004 strike at a Japanese-owned electronics factory: "After the strike, the Japanese general manager offered promotions and higher wages to the suspected strike leaders ... When their interests were separated from their workers' interests, these team leaders drifted towards management". Having temporary and rotating leadership prevents this from happening.

There are workers who are more politically conscious and militant than others, and who have a greater knowledge of labour law than others. Some are linked to independent labour rights groups either as members or, more frequently, as contacts who have previously approached the groups for advice (eleven interviews with seven workers and four labour activists, 22 October 2017 to 10 June 2018). These workers certainly play an important role in informing their colleagues about, for example, the implications of certain policies, and trying to persuade them to strike and resist. Other workers also approach them with questions or for advice. In this sense, such workers are vital in pushing strikes and building solidarity. They are not necessarily, however, consciously recognised as leaders by their co-workers. One worker-activist with Viet Labour said that almost all strikes have no leaders (interview, 12 April 2018).

As noted above, wildcat strikes are effective, and the Vietnamese working class has found a form of resistance which is successful in this epoch of flexible, neo-liberal production. It does not mirror a trade union or WRO-led strike. Implementing Western-style worker organisations - even in the limited form of WROs - does not fit easily with the current forms of militancy. Indeed, it is very much a reform from above.

\section{Demanding WROs}

Since existing, wildcat forms of resistance have worked, workers are not demanding independent unions or WROs; such demands have come from capital. I have never found an instance of workers demanding an independent worker organisation which is not part of the VGCL. In interviews, even independent labour activists from Viet Labour and Viet Labour Movement, who have as one of their main aims the development of independent trade unionism, admitted that workers have never demanded independent unions (three interviews, 25 July 2017 to 12 April 2018). One worker-activist attached to Viet Labour added that he was sure that there would not be a case of workers demanding independent representation within the next few years (interview, 12 April 2018). A VGCL lawyer also confirmed that he has never come across a case of striking workers 
demanding independent representation (interview, 30 March 2018). ${ }^{6}$

Rather, calls for WROs have come not from workers but from sections of industrial capital supported by the state - desperate to stop wildcat strikes and create smoother capitalist production. This was pointed out by Pham Thi Loan, a member of the National Assembly and director of an investment company, in an interview with the BBC in 2015. Pham said that employers want independent unions which will genuinely represent the voice of workers (đại diện cho tiếng nói của người lao động) because wildcat strikes are too damaging and capitalists cannot have peace of mind (không yên tâm); if workers had independent unions, employers could have negotiations and dialogue to prevent damaging work stoppages (Pham, in Quoc Phuong, 2015).

Building "harmonious labour relations" (quan hệ lao động häi hoa) is a euphemism meaning "stop strikes" - that is, stop the single most important thing which has led to higher wages, better working conditions and progressive labour reforms. The VGCL celebrates when strike numbers fall, and one of its main aims every year is to further reduce strikes (Ngo, in Hoang Manh, 2019; TEA, 2020). Similarly, Better Work Vietnam - an ILO initiative to improve conditions and increase productivity in the garment industry - has reducing strikes as an explicit aim of their project (Anner, 2017). The legalisation of WROs is also in this vein. Freedom of association reforms should, then, be seen not as "a significant step forward for free labor in Vietnam" (Tran and Bales, 2017: 93), but as an attempt by capital to reduce labour militancy. As Azzellini and Kraft write in an edited volume on self-organised workers' struggles:

Traditional unions are part of the institutional setting to maintain capitalism.... On the one hand, this is because the more radical workers' struggles and tendencies placed high pressure on the entrepreneurs and the capitalist system; therefore, employers preferred to deal with traditional unions to undermine workers' autonomy and reproduce the representative system. On the other hand, the capitalist system needed a reliable workers' mass that would stick to agreements and therefore provide the employers with a more accurate planning capacity (Azzellini and Kraft, 2018: 4-5).

In the Vietnamese case, we can say that employers would have preferred to deal with a state-led union federation. This has, however, failed to co-opt the working class and stop labour militancy. As a result, capital now wants to deal with WROs as a new attempt to undermine "workers' autonomy" and reproduce "the representative system" (Azzellini and Kraft, 2018).

\section{Conclusion}

This article has interrogated Vietnam's freedom of association reforms, providing a more sceptical tone compared to other commentary. I first outlined the current situation of labour politics in Vietnam, and then explained what the reforms are and where they came from. They were a result of both internal, bottom-up pressure from wildcat strikes - leading to the desire to create

\footnotetext{
${ }^{6}$ The one exception I know of was a January-February 2010 strike at a Taiwanese-owned shoe factory in the Mekong Delta. The strike was primarily over wages, benefits and unpaid social insurance, but the dynamics of the strike were very different to others. Independent labour activists, who were not workers at the factory, were heavily involved. Before the strike, activists had stayed in the area for three months, at first trying to understand the workers' situation and then providing guidance on how to strike. During the strike, activists gave advice to workers and distributed flyers. They encouraged workers to continue the strike for seven days. Due to this influence, workers did begin to discuss independent unions and representation; independent labour activists see this as an important milestone in the development of their movement (interviews with five independent labour activists, 25 July 2017 to 21 January 2018).
} 
harmonious labour relations - and external, top-down pressure from trade agreements. I then explained some of the main critiques of WROs, noting that they are not unions and are limited in what they can do compared to unions. I also noted that the free operation of worker organisations will be restricted by an authoritarian state.

I then suggested, however, that those perspectives are based on a fetishism of trade unions, which compares reforms to an imagined ideal of independent trade unionism and tripartism (Atzeni, 2020, 2021). I proposed rejecting this fetishism, and instead using a class analysis, assessing the reforms against actually existing social relations and labour struggles. From this perspective, I argued, there are more fundamental critiques to be made of Vietnam's freedom of association reforms. First, the country is implementing such reforms while further embedding itself into neoliberal capital flows and global production networks, the very form of capitalism that undermined trade unionism in other parts of the world. Second, the current organisational form of wildcat strikes does not easily fit into a WRO structure. Third, workers are not demanding WROs; capital is. The reforms, therefore, seem very detached from grassroots militancy. The Vietnamese working class has developed forms of decentralised struggle which have brought real gains at a time when workers' movements elsewhere have been, to put it mildly, less successful. WROs, modelled as they are on Western trade unionism and imposed from above, do not build on workers' existing associational power, but are a different type of organisation.

One may wonder whether wildcat strikes are fundamentally limited, as they have not formed, and perhaps cannot form, any movement which is challenging overall structures of capital accumulation or wants to transcend capitalist social relations. For all of Alquati's enthusiasm about wildcat strikes, he saw them as "a transitional phenomena [sic], a temporary measure until a more adequate form of organisation could be found" (in Wright, 2017: 70). This may be true, and, indeed, as I mentioned above, low wages and poor working conditions have become a structurally embedded feature of Vietnam's participation in global production networks and insertion into the global division of labour (Masina and Cerimele, 2018). Wildcat strikes have seemingly not managed to alter the highly exploitative nature of such participation and insertion. Nevertheless, I hope that I have demonstrated that wildcat strikes cannot just be dismissed as "primitive revolts" or "outbursts of desperation and vengeance" (Lenin, 1960: 374, 375); to do so would be "blind to the real power developed and held by workers today" (Cleaver, 1979: 41). Wildcat strikes in Vietnam have led to substantial gains for the Vietnamese working class, and not only in terms of immediate wage demands. Is it not ironic (although unsurprising) that, in one of the few places worldwide where workers have actually been struggling and winning in recent decades, their methods have come to be seen as a major problem which needs to be solved?

Perhaps wildcat strikes and WROs could work in tandem, with workers making use of both to make bigger and broader demands. This article, though, has highlighted how the development of WROs has not come from the grassroots, has not been a development building on wildcat militancy, but is a reaction against such militancy. The excitement and optimism about the proposed reforms from pro-labour quarters may, therefore, be misplaced. They will certainly not be a panacea. Indeed, as noted in this article, the aim of labour relations reforms, the rallying cry of state and capital, is very explicitly to build "harmonious labour relations" (quan hệ lao dộng baì hoa) - that is, to stop strikes. We must, then, approach the freedom of association reforms carefully and warily. Far from providing the basis for a new era of worker power, they may help capital weaken and fragment such power. Strike numbers have already been falling for the past couple of years (TEA, 2020), although they rose again slightly in 2020 in response to the coronavirus pandemic (Hoang Manh, 2021). Any freedom of association reforms should not be based on an imagined, reified ideal of what trade unions and labour relations should be, but should instead build 
on actually existing class composition and struggle. At the very least, let us hope that the Vietnamese working class can take these reforms and use them to increase their power, rather than allowing it to be fragmented.

\section{References}

Alquati, R. (2013) Struggle at FIAT. Viewpoint Magazine [online]. https://www.viewpointmag.com/ 2013/09/26/struggle-at-fiat-1964/ (accessed 15 January 2020).

Amnesty International (2019) Prisoners of Conscience in Vietnam. https://www.amnesty.org/ download/Documents/ASA4103032019ENGLISH.pdf (accessed 13 February 2020).

Anner, M. (2015) Worker Resistance in Global Supply Chains: Wildcat Strikes, International Accords and Transnational Campaigns. International Journal of Labour Research, 7(1-2): 17-34.

Anner, M. (2017) Wildcat Strikes and Better Work Bipartite Committees in Vietnam: Toward an Elect, Represent, Protect and Empower Framework. Better Work Discussion Paper 24. https://betterwork.org Lportfolio/12829 (accessed 29 September 2017).

Anner, M. (2018) CSR Participation Committees, Wildcat Strikes and the Sourcing Squeeze in Global Supply Chains. British Journal of Industrial Relations, 56(1): 75-98.

Atzeni, M. (2020) Workers' Organisation in Precarious Times: Abandoning Trade Union Fetishism, Rediscovering Class. Global Labour Journal, 11(3): 311-314.

Atzeni, M. (2021) Workers' Organisations and the Fetishism of the Trade Union Form: Toward New Pathways for Research on the Labour Movement? Globalizations, https://doi.org/10.1080/14747731.2021.1877970.

Azzellini, D. and M.G. Kraft (2018) Introduction: A Return to the Shop-floor or How to Confront Neoliberal Capitalism. In The Class Strikes Back: Self-Organised Workers'Struggles in the Twenty-First Century, edited by D. Azzellini and M.G. Kraft. Chicago, IL: Haymarket Books.

Breman, J. and M. van der Linden (2014) Informalizing the Economy: The Return of the Social Question at a Global Level. Development and Change, 45(5): 920-940.

Buckley, J. (2020a) Mapping Ride-hailing App Driver Strikes in Vietnam. New Mandala [online], 16 December. https://www.newmandala.org/mapping-ride-hailing-app-driver-strikes-in-vietnam (accessed 16 December 2020).

Buckley, J. (2020b) The Role of Labour Activism in Vietnam's Coronavirus Success. Equal Times [online], 2 July. https://www.equaltimes.org/the-role-of-labour-activism-in\#.X-X1nGT7S3I (accessed 16 December 2020).

Ca Dao (2019) Công đoàn trong luật Lao động mới có thật sự độc lập? [Are Unions in the New Labour Code Really Independent?]. Tiếng Dân [online], 14 December. https://baotiengdan.com/ 2019/12/14/cong-doan-trong-luat-lao-dong-moi-co-that-su-doc-lap (accessed 15 December 2019).

Campbell, S. (2013) Solidarity Formations under Flexibilisation: Workplace Struggles of Precarious Migrants in Thailand. Global Labour Journal, 4(2): 134-151.

Cerimele, M. (2018) Informalizing the Formal: Work and the Dual Dormitory Labor Regime in Hanoi's Thang Long Industrial Park. In Searching for Work: Small-Scale Mobility and Unskilled Labor in Southeast Asia, edited by S. Vignato and M.C. Alcano. Chiang Mai: Silkworm Books.

Clarke, S. (2006) The Changing Character of Strikes in Vietnam. Post-Communist Economies, 18(3): 345-361.

Cleaver, H. (1979) Reading Capital Politically. Brighton: The Harvester Press.

Cooney, S. and T.K.T. Tran (2019) Dispute Resolution in Vietnam: A Rapid Diagnosis, Geneva: ILO. 
Cox, A. (2015) The Pressure of Wildcat Strikes on the Transformation of Industrial Relations in a Developing Country: The Case of the Garment and Textile Industry in Vietnam. Journal of Industrial Relations, 57(2): 271-290.

Daubler, W. (2018) Trade Union Pluralism in Vietnam - Coping with Informal Associations. In Trade Unions in Transition: From Command to Market Economies, edited by R. Traub-Mertz and T. Pringle. Berlin: Friedrich Ebert Stiftung.

Do., H.H. (2016) The Dynamics of Legal Transplantation: Regulating Industrial Conflicts in Post-Đổi mới Vietnam. PhD thesis, University of Melbourne.

Do, Q.C. (2011) Understanding Industrial Relations Transformation in Vietnam: A Multi-dimensional Analysis. PhD thesis, University of Sydney.

Do, Q.C. (2017) The Regional Coordination of Strikes and the Challenge for Union Reform in Vietnam. Development and Change, 48(5): 1052-1068.

Do, Q.C. and D.v.d. Broek (2013) Wildcat Strikes: A Catalyst for Union Reform in Vietnam? Journal of Industrial Relations, 55(5): 783-799.

Friedrich Ebert Stiftung (FES) (2018) As Vietnam Revises Labour Law, FES and Partners Debate the Opportunity to Improve Workers' Rights. Friedrich Ebert Stiftung [online], 7 November. https://www.fes-asia.org/news/as-vietnam-revises-labour-law-fes-and-partners-debate-theopportunity-to-improve-workers-rights/ (accessed 12 February 2020).

Fujita, M. (2020) Comment on “Has Nguyen Phu Trong's Leadership Curbed Economic Reform? Economic Reform Trends in Vietnam". Asian Economic Policy Review, 15: 323-324.

Gray, H. (2018) Turbulence and Order in Economic Development: Institutions and Economic Transformation in Tanzania and Vietnam. Oxford: Oxford University Press.

Hoang Manh (2019) Các cuộc ngừng việc, đình công trong toàn quốc giảm 35\% [Nationwide Work Stoppages and Strikes Reduced by 35\%]. Dân Trí [online], 14 March. https://dantri.com.vn/vieclam/cac-cuoc-ngung-viec-dinh-cong-trong-toan-quoc-giam-35-20190314060650590.htm (accessed 16 March 2019).

Hoang Manh (2021) 126 cuộc ngừng việc tập thể trong năm 2020 [126 Collective Work Stoppages in 2020]. Dân Trí [online], 9 January. https://dantri.com.vn/lao-dong-viec-lam/126-cuoc-ngung-viec-tap-thetrong-nam-2020-20210109093951160.htm (accessed 10 January 2021).

International Labour Organization (ILO) (2013) National Wage Council Launched, Giving Employers and Workers a Voice in Minimum Wage Setting. ILO Vietnam [online], 3 August. https://www.ilo.org/hanoi/Informationresources/Publicinformation/WCMS 218763/lang-en/index.htm (accessed 4 November 2019).

International Labour Organization (ILO) (2019a) ILO Welcomes Viet Nam's Vote to Ratify ILO Fundamental Convention on Collective Bargaining. ILO Vietnam [online], 14 June. https://www.ilo.org/hanoi/Informationresources/Publicinformation/newsitems/WCMS 71 0542/lang--en/index.htm (accessed 17 December 2019).

International Labour Organization (ILO) (2019b) Vietnam Ratifies the Collective Bargaining Convention. ILO Vietnam [online], 26 July. https://www.ilo.org/global/standards/subjects-covered-byinternational-labour-standards/collective-bargaining/WCMS 713933/lang--en/index.htm (accessed 17 December 2019).

International Labour Organization (ILO) (2019c) Revised Vietnamese Labour Code to Help Everyone Gain Fair Shares of Economic Growth. ILO Vietnam [online], 20 November. https://www.ilo.org/hanoi/Informationresources/Publicinformation/newsitems/WCMS 72 9339/lang--en/index.htm (accessed 17 December 2019).

Kerkvliet, B.J.T. (2019) Speaking Out in Vietnam: Public Political Criticism in a Communist Party-Ruled Nation, Ithaca, NY, and London: Cornell University Press. 
Lenin. V.I. (1960) What is to be Done? Burning Questions of our Movement. In Collected Works, Volume 5: May 1901-February 1902, by V.I. Lenin, translated by J. Fineberg and G. Hanna, edited by V. Jerome. Moscow: Progress Publishers.

Masina, P. and M. Cerimele (2018). Patterns of Industrialisation and the State of Industrial Labour in PostWTO-Accession Vietnam. European Journal of East Asian Studies, 17: 289-323.

Pham, N.T. (2016) Các cam kết về lao động trong hiệp định đối tác chiến lược xuyên Thái Bình Dương - TPP [Labour Commitments in the Trans-Pacific Partnership Agreement - TPP]. Nghiên cúru Lập pháp [Legislative Research] [online]. http://www.lapphap.vn/Pages/TinTuc/208368/Cac-cam-ketve-lao-dong-trong-hiep-dinh-doi-tac-chien-luoc-xuyen-Thai-Binh-Duong---TPP.html (accessed 13 February 2020).

Pham, N.T. (2017) Trade and Labour Rights: The Case of the TPP. University of Oxford Global Economic Governance Programme Working Paper 124. https://www.geg.ox.ac.uk/sites/ geg.bsg.ox.ac.uk/files/GEG\%20WP\%20124\%20-\%20Trade\%20\%26\%20Labour\%20Rights \%20\%20The $\% 20$ Case $\% 20$ of $\% 20$ the $\% 20$ TPP $\% 20-\% 20$ Nghia $\% 20$ Trong $\% 20$ Pham 0.pdf (accessed 13 February 2020).

Pham, T.T.L. (2019) Collective Bargaining in Vietnam. Hanoi: ILO. https://www.ilo.org/wcmsp5 Lgroups/public/---asia/---ro-bangkok/---ilo-hanoi/documents/publication/wcms 715206. pdf (accessed 19 February 2020).

Pravda, A. and B.A. Ruble (1986) Communist Trade Unions: Varieties of Dualism. In Trade Unions in Communist States, edited by A. Pravda and B.A. Ruble. Boston, London and Sydney: Allen \& Unwin Ltd.

Pringle, T. and S. Clarke (2011) The Challenge of Transition: Trade Unions in Russia, China and Vietnam. Basingstoke: Palgrave Macmillan.

Quan, K. (2015) One Step Forward: Collective Bargaining Experiments in Vietnam and China. In Chinese Workers in Comparative Perspective, edited by A. Chan. Ithaca, NY, and London: Cornell University Press.

Quoc Phuong (2015) Phong trào công nhân VN đã trưởng thành [The Vietnamese Workers’ Movement has Matured]. BBC Vietnamese [online], 3 April. https://www.bbc.com/vietnamese Lvietnam/2015/04/150402 hangout dinhcong tantao (accessed 13 February 2020).

Siu, K. and A. Chan (2015) Strike Wave in Vietnam, 2006-2011. Journal of Contemporary Asia, 45(1): 71-91.

T.E.A. (2020) Số cuộc ngừng việc tập thể giảm gần 50\% [Collective Work Stoppages Reduce by Nearly 50\%]. Lao Động [online], 7 January. https://laodong.vn/cong-doan/so-cuoc-ngung-viec-tap-thegiam-gan-50-776934.1do (accessed 8 January 2020).

Trade Justice Pilipinas (2020) RCEP an Unjust Deal and Added Burden in the Time of a Pandemic. Focus on the Global South [online], 15 November. https:/ / focusweb.org/rcep-an-unjust-deal-and-addedburden-in-the-time-of-a-pandemic (accessed 27 December 2020).

Tran, A.N. (2007) Alternatives to the "Race to the Bottom" in Vietnam: Minimum Wage Strikes and their Aftermath. Labor Studies Journal, 32(4): 430-451.

Tran, A.N. (2013) Ties That Bind: Cultural Identity, Class, and Law in Vietnam's Labor Resistance. Ithaca, NY: Cornell University Press.

Tran, A.N. (2015) Small Victory, Systemic Problems. New Mandala [online], 30 April. https://www.newmandala.org/small-victory-systemic-problems (accessed 29 September 2019).

Tran, A.N. (2018) Workers Say No to Vietnam’s “Special Exploitation Zones”. New Mandala [online], 18 July. $\quad$ https://www.newmandala.org/workers-say-no-vietnams-special-exploitation-zones (accessed 29 September 2019).

Tran, A.N., J. Bair and M. Werner (2017) Forcing Change from the Outside? The Role of Trade-labour Linkages in Transforming Vietnam’s Labour Regime. Competition \& Change, 21(5): 397-416. 
Tran, T.K.T. and R. Bales (2017) On the Precipice: Prospects for Free Labor Unions in Vietnam. San Diego International Law Journal, 19(1): 71-94.

United Nations (UN) Office of the High Commissioner for Human Rights (2018) Vietnam: UN Experts Concerned by Threats against Factory Workers and Labour Activists. United Nations Human Rights Office of the High Commissioner [online], 20 March. https://www.ohchr.org/EN/NewsEvents/Pages/ DisplayNews.aspx?NewsID=22852\&LangID $=\mathrm{E}$ (accessed 13 February 2020).

Van der Linden, M. (2008) Workers of the World: Essays toward a Global Labor History. Leiden and Boston: Brill.

Van der Linden, M. (2016) Global Labour: A Not-so-grand Finale and Perhaps a New Beginning. Global Labour Journal, 7(2): 201-210.

Vietnam General Confederation of Labour (VGCL) (2014) Điều lệ công đoàn Việt Nam (Đại hội Công đoàn Việt Nam lần thứ XI thông qua ngày 30 tháng 7 năm 2013) [Vietnam Trade Union Charter (passed by the XI Trade Union Congress on 30 July 2013)]. In 85 năm (28/7/1929-28/7/2014) Công đoàn Việt Nam Xây dụng và Phát triên [85 years (28/7/1929-28/7/2014) of Building and Developing the Vietnamese Trade Union], edited by T. Tai and T. Vu. Hanoi: Labour and Society Publishing House.

Wright, S. (2017) Storming Heaven: Class Composition and Struggle in Italian Autonomous Marxism. Second edition. London: Pluto Press.

\section{Legislation}

Bộ luật Lao động 2019, 45/2019/QH14. Chương XIII: Tổ chức đại diện người lao động tại cơ sở [Labour Code 2019, 45/2019/QH14. Chapter XIII: Grassroots-level Worker Representative Organisations]. https://thuvienphapluat.vn/van-ban/lao-dong-tien-luong/Bo-Luat-lao-dong-2019333670.aspx (accessed 6 February 2020).

Comprehensive and Progressive Agreement for Trans-Pacific Partnership 2018. https://www.international.gc.ca Ltrade-commerce/trade-agreements-accords-commerciaux/agr-acc/cptpp-ptpgp/texttexte/index.aspx (accessed 13 February 2020).

EU-Vietnam Free Trade Agreement 2018, Chapter 13: Trade and Sustainable Development. http://trade.ec.europa. eu/doclib/docs/2018/september/tradoc 157373.pdf (accessed 13 February 2020).

Luật Công đoàn 2012 [Trade Union Law 2012]. https://thuvienphapluat.vn/van-ban/Lao-dong-Tienluong/Luat-Cong-doan-2012-142186.aspx (accessed 6 February 2020).

United States-Viet Nam Plan for the Enhancement of Trade and Labour Relations, 2016. https://ustr.gov/ $\underline{\text { sites/default/files/TPP-Final-Text-Labour-US-VN-Plan-for-Enhancement-of-Trade-and- }}$ Labor-Relations.pdf (accessed 13 February 2020).

\section{ACKNOWLEDGEMENTS}

Thanks to Georgina Alonso, Michael Haack, John Hutnyk, Anthony Morreale, Tim Pringle and two anonymous reviewers for very useful comments on earlier versions of the paper. The research was supported by the UK Economic and Social Research Council (ESRC) under grant number 24ES/J500021/1.

\section{BIOGRAPHICAL NOTE}

JOE BUCKLEY is an independent labour researcher who has taught, written and consulted widely on labour and union issues in the Global South, especially Southeast Asia. His PhD, completed in 2020, focused on Vietnamese labour activism, and is currently being adapted into a book manuscript. [Email: joejbbuckley@gmail.com] 